\title{
Ranking Priorities Performance variables of GSCM for in Indian Automobile Organizations
}

\author{
Deepak kumar pathak, Ajay verma
}

\begin{abstract}
The paper aims to identify key performance variables of green supply chain management (GSCM) practices to achieve sustainable development goals. It develops a comprehensive structural relationship between various performance variables for GSCM for sustainability in Indian automobile industries. With the help of expert opinions from industry professionals and extant literature review, fifteen key performance variables have been identified and stated as these variables attempt to achieve the sustainability goals in GSCM practices. The Technique for Order Preference by Similarity to the Ideal Solution (TOPSIS) method is employed to develop the model and then rank them. The results of this study show that supplier willingness towards GSCM, Adoption of technology advancement adoption, and top management commitment have emerged as top three key variables while organizational motivating, encouragement of sustainable product, and government support systems are identified as the bottom three parameters. It also helps to achieve the priority basis to create a greener platform in the automobile industry. The study helps the managers, practitioners, and policymakers in making strategic and tactical decisions for better sustainability in the Indian Automobile industries in the context of GSCM practices. The critical inputs show the GSCM in the firms being more proactive and well prepared. The novelty of this research lies in the requirement of GSCM as most automobile companies set up their plants for awareness of economic, social and environmental development. The performance variable identified to improve organizational performance to contribute to sustainable development improvements in the practices and policies.
\end{abstract}

Keywords: Green supply chain management (GSCM), Performance Variables, TOPSIS method, Sustainability, Indian Automobile industry

\section{INTRODUCTION}

There has been a changing trend in management as well as the operation of global manufacturing. These environmental and social issues are becoming more critical in managing any corporation. As well, in the production system of corporations, the top management is considering the terms 'production quality and standards' as an essential element. In the context of increasing pressure from global competition, manufacturing enterprises must pay attention to two parallel aspects, namely quality and cost-saving issues. (Zhu and Sarkis, 2006). As the new approach, green supply chain

Revised Manuscript Received on June 22, 2020.

* Correspondence Author

Deepak kumar pathak*, Reasearch scholar, Department of Mechanical Engineering, MANIT BHOPAL,India ,Email.deepakmadan89@gmail.com

Dr. Ajay verma, Assistant professor, Department of Mechanical Engineering, MANIT BHOPAL,India,Email.avmanit@gmail.com

(C) The Authors. Published by Blue Eyes Intelligence Engineering and Sciences Publication (BEIESP). This is an open access article under the CC BY-NC-ND license (http://creativecommons.org/licenses/by-nc-nd/4.0/) management (GSCM) During the last decades, despite corporate responsibility for global sustainability is playing an increasingly important role in the modern production system. Nonetheless, the on-going production process lacks attention in the value of issues related to the social and environmental of corporate. It is clear that from the world statistics findings that the manufacturing industry is the largest manufacturing area worldwide (Sahoo et al., 2011). Previous studies on the combination of business performance and green manufacturing often take place in developed countries, while research gaps in developing countries are enormous. (Dangelico and Pujari, 2010; Esfahbodi et al., 2016). From this point of view, the Indian manufacturing industry plays a key role at the global level. It has led that more MNC's have started their production actives in India. Regarding the argument about sustainability that it is green production issues must be integrated into the development strategy of manufacturers (Jabbour et al., 2016). The whole GSCM's systems from up-stream to down-stream must incorporate corporate responsibility aims to minimize adverse impacts on local inhabitants as well as the ecological environment while getting better production performance (Katiyar and Barua, 2013). Hence, identifying the performance variable that may affect the implementation of GSCM in the automobile industry is essential, especially in the context of an emerging economy. Nowadays companies make efforts to find out the performance variable and prevent them in performance improvement and sustain the supply chain process. However, still, they are unable to implement GSCM. This research paper aims to follow these research questions such that: (i) what are the GSCM focused performance variables to developing sustainability in Automobile organizations? (ii) How the listed performance variable is inter-related for accomplishing sustainability in Automobile organizations?

This paper endeavors to address the above-stated research questions and set out the following research aims: (i) To identify various GSCM focused performance variable to developing sustainability in Automobile organizations; (ii) To construct a contextual relationship between identified performance variable and analyze their effects for sustainable business development; (iii) To draw significant implications of the research.

\section{LITERATURE REVIEW}

Evaluation of Green Supplier Performance, The supplier evaluation process is an important element in supplier-based manufacturing and SCM has been gaining attention in both the academic literature and industrial practice. The supplier selection decision is one of the critical and important issues in SCM for many organizations to help maintain a strategically competitive position Qiang

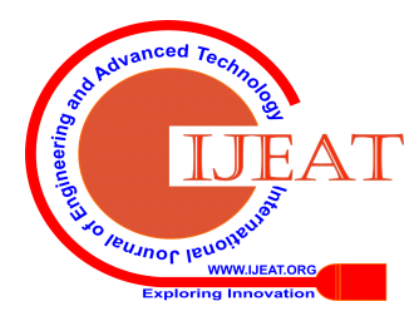


Hou and Lei Xie (2019). Balasubramanian (2012) also connected to the Indian industry in green supply chain development source in India. Tseng (2013) mentioned demonstrating the level of reliance on the driving power dependency criterion. The focus of environmental management has shifted from the organization level to the supply chain level (Kumar and Chandrakar, 2012; and Green et al., 2012). Many studies have been carried out on Environment and social performance (Easton and Carter, 2011). The researchers who have identified a green supply chain with sustainability created all around the Automobile industry and focused then on the environmental performance part of sustainable development.The environment development has to identify the supply chain in association (winter and Knemeyer, 2013; Ahi and Searcy, 2013; and Lin, 2013), which identified the GSCM performance in coordinating the material flow through the supply chain to fulfill the criterion of the interest the delivery of the product. The supply chain endeavors the keep up the inward wellbeing and environment sustainable to utilizing the ability the self-dependent data from the outward the environment. As the supply chain which becomes the mind full to a customer request for the items and the administration gave which is without any harm the environment. Furthermore, the top management with its role in the manufacturing enterprises must show the commitment to the community via corporate social responsibility activities. Besides, the engagement also means integrating all the stakeholders of the supply chain, including reverse logistics as well as to other organizations (González-Torre et al., 2010). The industry-specific performance variable has specific limits that hinder the application of ecological practices in production, which leads to constraints for businesses that want to improve their competitive advantage (Mathiyazhagan et al., 2013). Besides the industry-specific performance variable proposed, there are two performance variables as external industrial and firm performance also impact GSCM (González-Torre et al., 2010). In supply chain which has to increase the upper hand by the analysis of the environment to execute green supply chain management in the Indian industry. Modern customers are not only concerned with product quality, but also in their origin or manufacturing process of the goods. Their knowledge and perception of the product are very significant, leading to public opinion in an environmentally friendly product (Mathiyazhagan et al., 2013). Mathiyazhagan et al. (2013) kept portraying the likelihood of the green supply multiplier impact coming about because of the joint effort to the green supply chain to issue concerning the environment. In the context of US manufacturing firms, Green et al. (2012) have utilized the SEM approach to test the effectiveness of GSCM practices. The findings proved that the effect for Automobile companies is significant when it is possible to improve the performance of both three critical aspects simultaneously, namely, environmental, economic, and operational performance (Green et al., 2012). Further Rao and Holt (2005) have focused on the current research that gives some heading yet stays uncertain.

The gaps in the systematic review from previous studies have enabled scholars to explore and research new complex issues in each different situation. In the industrial GSCM practices will face many differences as well as account the needs and satisfy its stakeholders. Generally, GSCM practices are central develops in the speculated model with inside environmental management and green data systems as forerunners and environmental, monetary, operational, and hierarchical performance as results. In addition, it also based on theory and capacity building, a factor that considered internal performance measurement cannot be ignored that the development of necessary technical competence (Cavusgil et al., 2007). The risks increasing caused by the instability of the legal environment in each country create uncertainty in the business strategy of companies, especially the Automobile industry. Hence, the authors argue that these Automobile industries may have witnessed more pressure to attempt environmental policies.

\subsection{Performance variables for GSCM in Indian Automobile industry.}

This research identified the Performance Variables for of GSCM practices in the Indian Automobile industries scenario and applied in Automobile industries that show the current Indian scenario. We have analysed all the parameter, which affect the present scenario in the Automobile sector. In India, not very effectively implement the environment action taken by the government, by the information technology (IT) implication, which not very effectively utilized the information technology it is the symmetric and technology-system, which is very necessary for providing support in the product life cycle. organizational motivating in which all the interrelation to improve the association to receive green per formation (Balasubramanian and Sundarakani, 2019). GSCM in any organization is very useful to the development program for the design for the environment and which improve the green supply chain philosophy so that cost of its implication to carrying out important performance to utilize improvement of GSCM practices. Government support to implies the market lack certainty in worldwide contender to create and convey the procedure. In this market competition and uncertainty is high in the present situation, the innovating green practices in which collection of the green supply knowledge in this situation, in hierarchical support the quality of human recourses. Actualising GSCM financial constraints likewise lead to protection from green practices. top- level management commitment to in this manner we accept that the top-level management duty is among of these performance variable to the GSCM in the Automobile industry. Thanks to combinations from the systematic literature reviews and expert perspectives, the authors have identified performance variable to implement GSCM in the context of the Indian Automobile industry. The results of previous studies have presented essential factors that are considered as performance variable to the application of GSCM. The authors evaluated the effects of earlier studies in different contexts, focusing on the reviews of the Indian Automobile industry aims to point out the performance variable of GSCM. Through the enthusiastic help of eight experts, including four experts from Indian industries and four experts from academia. As a result, fifteen relevant performance variables to the Indian Automobile industry were identified.

Published By:

Blue Eyes Intelligence Engineering 
These performance variable are Encouragement IT Implementation; Protection from Technology Advancement Adoption; Organization Motivating; Quality of Human Resources; Market Competition and Uncertainty; Government Support systems; Innovating Green Practices; Top Management Commitment; Cost Implications; Supplier Reluctance to change towards GSCM; customers awareness. All of those factors are considered as performance variables implementation of GSCM in the Indian Automobile industry

\section{2 performance variable given below}

1. Encouragement of sustainable product (P1)

2. Corporate social responsibility (P2)

3. Environmental partnership (P3)

4. Effective environmental measures(P4)

5.IT Implementation (P5)

6. Adoption of technology advancements (P6)

7.Organizational Motivating(P7)

8. Quality of Human Resources(P8)

9. Market Competition and Uncertainty(P9)

10. Government Support systems(P10)

11. Innovating Green Practices(P11)

12. Top Management Commitment(P12)

13. Cost Implications(P13)

14. Supplier Willingness towards GSCM (P14)

15. Customers awareness(P15)

\section{TOPSIS METHOD}

For the positioning of various parameters, a multi-criteria decision making (MCDM) tool is utilized. The system called TOPSIS was proposed as the most generally MCDM strategy by Hwang also, Yoon (1981) while first presented by Chen (2000) to take care of the MCDM issues under uncertainty and dubiousness. Now a day various researchers utilized the data under TOPSIS (Singh et al., 2016). In this paper, fifteen criteria and five DMs have been considering in this study now the TOPSIS method is applied in this problem to deal with unstructured problems. TOPSIS method assumptions are checked before going to apply including interrelation among the independent and dependent factor early method. In this method, an expert-based method uses to give positioning the parameter with different experts' opinions (Wang and Lee (2009) and Singh et al. (2016)). Do et al. (2019) proposed the TOPSIS model analysis to prioritize in given equation

$C C_{i}=\frac{d_{i}^{-}}{d_{i}^{-}+d_{i}^{+}}, i=1,2, \ldots, m$

\section{RESULT AND DISCUSSION}

The flowchart of the proposed work shows the various TOPSIS steps to find the ranking of these identified GSCM performance variables as an important subject in decision making. This TOPSIS technique with virtual points (positive and negative ideal solutions) is commonly used to solve the multi attribute decision-making problems. There are five decision-makers (DMs such as DM1 to DM5), having good experience in automobile sectors, and belong to the top management levels of Indian automobile industries. In automobile production, organizational performance is needed for a company to beat its competitors and considered this one as the very important factor so, we identified most related performance variables from the previous literature that help to improve the organizational performance. Further, we tried to develop the model which give prioritizes them using the TOPSIS method. The analysis and prioritization of these variables would be highly helpful in making strategic and tactical decisions for better sustainability in the Indian automobile industries in the context of GSCM practices.

The execution of this model with top and bottom ranking and which variables should be given higher attention are presented in this section. Therefore, based on experience and the strategic choices of five decision-makers' opinion matter as they have given the weight of " 0.3, , " 0.2, , " 0.1 ", " 0.25 ," and " 0.15 ," respectively. These variables are given a score on a five-point Likert scale of 1-5 (1-very low, 2-low, 3-

medium, 4-high, and 5-very high).

\begin{tabular}{|c|c|c|c|c|c|c|}
\hline SN & Weight & 0.3 & 0.2 & 0.1 & 0.25 & 0.15 \\
\hline & & DM1 & DM2 & DM3 & DM4 & $\begin{array}{l}\text { DM } \\
5\end{array}$ \\
\hline 1 & P1 & 3 & 3 & 2 & 2 & 2 \\
\hline 2 & P2 & 4 & 3 & 3 & 3 & 4 \\
\hline 3 & P3 & 3 & 4 & 3 & 4 & 3 \\
\hline 4 & P4 & 3 & 3 & 4 & 4 & 3 \\
\hline 5 & P5 & 3 & 3 & 3 & 3 & 3 \\
\hline 6 & P6 & 4 & 5 & 4 & 5 & 5 \\
\hline 7 & P7 & 3 & 3 & 3 & 2 & 2 \\
\hline 8 & P8 & 4 & 3 & 3 & 3 & 3 \\
\hline 9 & P9 & 3 & 4 & 4 & 4 & 3 \\
\hline 10 & P10 & 3 & 2 & 2 & 2 & 2 \\
\hline 11 & P11 & 3 & 3 & 3 & 2 & 3 \\
\hline 12 & P12 & 5 & 5 & 5 & 4 & 5 \\
\hline 13 & P13 & 5 & 4 & 5 & 4 & 4 \\
\hline 14 & P14 & 4 & 5 & 5 & 4 & 4 \\
\hline 15 & P15 & 4 & 4 & 3 & 5 & 4 \\
\hline
\end{tabular}

Table 1: The scores of the decision matrix and weight from different experts Suggestion

\begin{tabular}{|c|c|c|c|c|c|c|}
\hline S & Weight & 0.3 & 0.2 & 0.1 & 0.25 & 0.15 \\
$\mathrm{~N}$ & & & & & & \\
\hline & & DM1 & DM2 & DM3 & DM4 & DM5 \\
\hline 1 & P1 & 0.2110793 & 0.20902 & 0.143592 & 0.145479 & 0.149071 \\
\hline 2 & P2 & 0.281439 & 0.20902 & 0.215387 & 0.218218 & 0.298142 \\
\hline 3 & P3 & 0.2110793 & 0.278693 & 0.215387 & 0.290957 & 0.223607 \\
\hline 4 & P4 & 0.2110793 & 0.20902 & 0.287183 & 0.290957 & 0.223607 \\
\hline 5 & P5 & 0.2110793 & 0.20902 & 0.215387 & 0.218218 & 0.223607 \\
\hline 6 & P6 & 0.281439 & 0.348367 & 0.287183 & 0.363696 & 0.372678 \\
\hline 7 & P7 & 0.2110793 & 0.20902 & 0.215387 & 0.145479 & 0.149071 \\
\hline 8 & P8 & 0.281439 & 0.20902 & 0.215387 & 0.218218 & 0.223607 \\
\hline 9 & P9 & 0.2110793 & 0.278693 & 0.287183 & 0.290957 & 0.223607 \\
\hline 1 & & & & & & \\
0 & P10 & 0.2110793 & 0.139347 & 0.143592 & 0.145479 & 0.149071 \\
\hline 1 & & & & & & \\
1 & P11 & 0.2110793 & 0.20902 & 0.215387 & 0.145479 & 0.223607 \\
\hline 1 & & & & & & \\
2 & P12 & 0.3517988 & 0.348367 & 0.358979 & 0.290957 & 0.372678 \\
\hline 1 & & & & & & \\
3 & P13 & 0.3517988 & 0.278693 & 0.358979 & 0.290957 & 0.298142 \\
\hline 1 & & & & & & \\
4 & P14 & 0.281439 & 0.348367 & 0.358979 & 0.290957 & 0.298142 \\
\hline 1 & & & & & & \\
5 & P15 & 0.281439 & 0.278693 & 0.215387 & 0.363696 & 0.298142 \\
\hline
\end{tabular}

Table 2: Normalized values of decision matrix

\begin{tabular}{|l|l|l|l|l|l|l|}
\hline & & \multicolumn{1}{|c|}{ DM1 } & \multicolumn{1}{|c|}{ DM2 } & \multicolumn{1}{|c|}{ DM3 } & \multicolumn{1}{|c|}{ DM4 } & \multicolumn{1}{c|}{ DM5 } \\
\hline 1 & & 0.04221 & 0.04180 & 0.02871 & 0.029 & 0.0298 \\
& P1 & 59 & 4 & 83 & 096 & 14 \\
\hline 2 & & 0.05628 & 0.04180 & 0.04307 & 0.043 & 0.0596 \\
& P2 & 78 & 4 & 75 & 644 & 28 \\
\hline
\end{tabular}

Published By:

Blue Eyes Intelligence Engineering 
Ranking Priorities Performance variables of GSCM for in Indian Automobile Organizations

\begin{tabular}{|c|c|l|l|l|l|l|}
\hline 3 & & 0.04221 & 0.05573 & 0.04307 & 0.058 & 0.0447 \\
& P3 & 59 & 86 & 75 & 191 & 21 \\
\hline 4 & & 0.04221 & 0.04180 & 0.05743 & 0.058 & 0.0447 \\
& P4 & 59 & 4 & 67 & 191 & 21 \\
\hline 5 & & 0.04221 & 0.04180 & 0.04307 & 0.043 & 0.0447 \\
& P5 & 59 & 4 & 75 & 644 & 21 \\
\hline 6 & & 0.05628 & 0.06967 & 0.05743 & 0.072 & 0.0745 \\
& P6 & 78 & 33 & 67 & 739 & 36 \\
\hline 7 & & 0.04221 & 0.04180 & 0.04307 & 0.029 & 0.0298 \\
& P7 & 59 & 4 & 75 & 096 & 14 \\
\hline 8 & & 0.05628 & 0.04180 & 0.04307 & 0.043 & 0.0447 \\
& P8 & 78 & 4 & 75 & 644 & 21 \\
\hline 9 & & 0.04221 & 0.05573 & 0.05743 & 0.058 & 0.0447 \\
& P9 & 59 & 86 & 67 & 191 & 21 \\
\hline 1 & P1 & 0.04221 & 0.02786 & 0.02871 & 0.029 & 0.0298 \\
0 & 0 & 59 & 93 & 83 & 096 & 14 \\
\hline 1 & P1 & 0.04221 & 0.04180 & 0.04307 & 0.029 & 0.0447 \\
1 & 1 & 59 & 4 & 75 & 096 & 21 \\
\hline 1 & P1 & 0.07035 & 0.06967 & 0.07179 & 0.058 & 0.0745 \\
2 & 2 & 98 & 33 & 58 & 191 & 36 \\
\hline 1 & P1 & 0.07035 & 0.05573 & 0.07179 & 0.058 & 0.0596 \\
3 & 3 & 98 & 86 & 58 & 191 & 28 \\
\hline 1 & P1 & 0.05628 & 0.06967 & 0.07179 & 0.058 & 0.0596 \\
4 & 4 & 78 & 33 & 58 & 191 & 28 \\
\hline 1 & P1 & 0.05628 & 0.05573 & 0.04307 & 0.072 & 0.0596 \\
5 & 5 & 78 & 86 & 75 & 739 & 28 \\
\hline
\end{tabular}

Table 3: Weighted values of decision matrix

\begin{tabular}{|c|c|c|c|c|c|c|}
\hline & & DM1 & DM2 & DM3 & DM4 & DM5 \\
\hline 1 & P1 & $\begin{array}{c}0.0017 \\
82 \\
\end{array}$ & $\begin{array}{c}0.00205 \\
1\end{array}$ & $\begin{array}{c}5.15 \mathrm{E}- \\
05\end{array}$ & $\begin{array}{c}0.00190 \\
5\end{array}$ & $\begin{array}{c}0.0006 \\
81\end{array}$ \\
\hline 2 & P2 & 0 & $\begin{array}{c}0.00205 \\
1 \\
\end{array}$ & $\begin{array}{c}5.15 \mathrm{E}- \\
05\end{array}$ & $\begin{array}{c}0.00084 \\
7 \\
\end{array}$ & $\begin{array}{c}1.39 \mathrm{E}- \\
05\end{array}$ \\
\hline 3 & P3 & $\begin{array}{c}0.0017 \\
82 \\
\end{array}$ & $\begin{array}{c}0.00098 \\
3 \\
\end{array}$ & $\begin{array}{c}5.15 \mathrm{E}- \\
05 \\
\end{array}$ & $\begin{array}{c}0.00021 \\
2 \\
\end{array}$ & $\begin{array}{c}0.0001 \\
25 \\
\end{array}$ \\
\hline 4 & P4 & $\begin{array}{c}0.0017 \\
82\end{array}$ & $\begin{array}{c}0.00205 \\
1\end{array}$ & $\begin{array}{c}0.0004 \\
64\end{array}$ & $\begin{array}{c}0.00021 \\
2\end{array}$ & $\begin{array}{c}0.0001 \\
25\end{array}$ \\
\hline 5 & P5 & $\begin{array}{c}0.0017 \\
82 \\
\end{array}$ & $\begin{array}{c}0.00205 \\
1 \\
\end{array}$ & $\begin{array}{c}5.15 \mathrm{E}- \\
05 \\
\end{array}$ & $\begin{array}{c}0.00084 \\
7 \\
\end{array}$ & $\begin{array}{c}0.0001 \\
25 \\
\end{array}$ \\
\hline 6 & P6 & 0 & 0 & $\begin{array}{c}0.0004 \\
64\end{array}$ & 0 & 0 \\
\hline 7 & P7 & $\begin{array}{c}0.0017 \\
82 \\
\end{array}$ & $\begin{array}{c}0.00205 \\
1 \\
\end{array}$ & $\begin{array}{c}5.15 \mathrm{E}- \\
05 \\
\end{array}$ & $\begin{array}{c}0.00190 \\
5 \\
\end{array}$ & $\begin{array}{c}0.0006 \\
81 \\
\end{array}$ \\
\hline 8 & P8 & 0 & $\begin{array}{c}0.00205 \\
1\end{array}$ & $\begin{array}{c}5.15 \mathrm{E}- \\
05\end{array}$ & $\begin{array}{c}0.00084 \\
7\end{array}$ & $\begin{array}{c}0.0001 \\
25\end{array}$ \\
\hline 9 & P9 & $\begin{array}{c}0.0017 \\
82\end{array}$ & $\begin{array}{c}0.00098 \\
3\end{array}$ & $\begin{array}{c}0.0004 \\
64\end{array}$ & $\begin{array}{c}0.00021 \\
2\end{array}$ & $\begin{array}{c}0.0001 \\
25\end{array}$ \\
\hline 10 & $\begin{array}{c}\mathrm{P} 1 \\
0\end{array}$ & $\begin{array}{c}0.0017 \\
82 \\
\end{array}$ & $\begin{array}{c}0.00350 \\
7 \\
\end{array}$ & $\begin{array}{c}5.15 \mathrm{E}- \\
05\end{array}$ & $\begin{array}{c}0.00190 \\
5\end{array}$ & $\begin{array}{c}0.0006 \\
81\end{array}$ \\
\hline 11 & $\begin{array}{c}\mathrm{P} 1 \\
1\end{array}$ & $\begin{array}{c}0.0017 \\
82\end{array}$ & $\begin{array}{c}0.00205 \\
1\end{array}$ & $\begin{array}{c}5.15 \mathrm{E}- \\
05\end{array}$ & $\begin{array}{c}0.00190 \\
5\end{array}$ & $\begin{array}{c}0.0001 \\
25\end{array}$ \\
\hline 12 & $\begin{array}{c}\mathrm{P} 1 \\
2 \\
\end{array}$ & $\begin{array}{c}0.0001 \\
98 \\
\end{array}$ & 0 & 0 & $\begin{array}{c}0.00021 \\
2 \\
\end{array}$ & 0 \\
\hline 13 & $\begin{array}{c}\text { P1 } \\
3\end{array}$ & $\begin{array}{c}0.0001 \\
98\end{array}$ & $\begin{array}{c}0.00098 \\
3\end{array}$ & 0 & $\begin{array}{c}0.00021 \\
2\end{array}$ & $\begin{array}{c}1.39 \mathrm{E}- \\
05\end{array}$ \\
\hline 14 & $\begin{array}{c}\mathrm{P} 1 \\
4\end{array}$ & 0 & 0 & 0 & $\begin{array}{c}0.00021 \\
2 \\
\end{array}$ & $\begin{array}{c}1.39 \mathrm{E}- \\
05\end{array}$ \\
\hline 15 & $\begin{array}{c}\text { P1 } \\
5\end{array}$ & 0 & $\begin{array}{c}0.00098 \\
3 \\
\end{array}$ & $\begin{array}{c}5.15 \mathrm{E}- \\
05\end{array}$ & 0 & $\begin{array}{c}1.39 \mathrm{E}- \\
05\end{array}$ \\
\hline
\end{tabular}

Table 4: Distance from the positive ideal solution $\left(d_{i}^{+}\right)$

\begin{tabular}{|c|c|c|c|c|c|c|}
\hline & & DM1 & DM2 & DM3 & DM4 & DM5 \\
\hline 1 & & 0.0040 & $4.85 \mathrm{E}-$ & & & \\
& P1 & 1 & 05 & 0 & 0 & 0 \\
\hline 2 & & 0.0024 & $4.85 \mathrm{E}-$ & 0.00082 & 0.0002 & 0.0013 \\
& P2 & 26 & 05 & 5 & 12 & 89 \\
\hline 3 & & 0.0040 & 0.0004 & 0.00082 & 0.0008 & \\
& P3 & 1 & 37 & 5 & 47 & 0.0005 \\
\hline 4 & & 0.0040 & $4.85 \mathrm{E}-$ & 0.00185 & 0.0008 & \\
& P4 & 1 & 05 & 6 & 47 & 0.0005 \\
\hline 5 & & 0.0040 & $4.85 \mathrm{E}-$ & 0.00082 & 0.0002 & \\
& P5 & 1 & 05 & 5 & 12 & 0.0005 \\
\hline 6 & & 0.0024 & 0.0012 & 0.00185 & 0.0019 & 0.0027 \\
& P6 & 26 & 14 & 6 & 05 & 22 \\
\hline 7 & P7 & 0.0040 & $4.85 \mathrm{E}-$ & 0.00082 & 0 & 0 \\
\hline
\end{tabular}

Retrieval Number: E9885069520/2020@BEIESP DOI: 10.35940/ijeat.E9885.069520

\begin{tabular}{|c|c|c|c|c|c|c|}
\hline & & 1 & 05 & 5 & & \\
\hline 8 & & 0.0024 & $4.85 \mathrm{E}-$ & 0.00082 & 0.0002 & \\
& P8 & 26 & 05 & 5 & 12 & 0.0005 \\
\hline 9 & & 0.0040 & 0.0004 & 0.00185 & 0.0008 & \\
& P9 & 1 & 37 & 6 & 47 & 0.0005 \\
\hline 1 & & 0.0040 & & & & \\
0 & P10 & 1 & 0 & 0 & 0 & 0 \\
\hline 1 & & 0.0040 & $4.85 \mathrm{E}-$ & 0.00082 & & \\
1 & $\mathrm{P} 11$ & 1 & 05 & 5 & 0 & 0.0005 \\
\hline 1 & & & 0.0012 & 0.00329 & 0.0008 & 0.0027 \\
2 & $\mathrm{P} 12$ & 0 & 14 & 9 & 47 & 22 \\
\hline 1 & & & 0.0004 & 0.00329 & 0.0008 & 0.0013 \\
3 & $\mathrm{P} 13$ & 0 & 37 & 9 & 47 & 89 \\
\hline 1 & & 0.0024 & 0.0012 & 0.00329 & 0.0008 & 0.0013 \\
4 & $\mathrm{P} 14$ & 26 & 14 & 9 & 47 & 89 \\
\hline 1 & & 0.0024 & 0.0004 & 0.00082 & 0.0019 & 0.0013 \\
5 & $\mathrm{P} 15$ & 26 & 37 & 5 & 05 & 89 \\
\hline
\end{tabular}

Table 5: Distance from the negativeideal solution $\left(d_{i}^{-}\right)$

\begin{tabular}{|c|r|r|r|r|c|}
\hline & & \multicolumn{1}{c|}{$d_{i}^{+}$} & \multicolumn{1}{c|}{$d_{i}^{-}$} & \multicolumn{1}{c|}{$C C_{i}$} & Rank \\
\hline 1 & P1 & 0.00647 & 0.004058 & 0.385474 & $14^{\text {th }}$ \\
\hline 2 & P2 & 0.002963 & 0.0049 & 0.623153 & $8^{\text {th }}$ \\
\hline 3 & P3 & 0.003153 & 0.006618 & 0.677287 & $7^{\text {th }}$ \\
\hline 4 & P4 & 0.004634 & 0.007261 & 0.610428 & $9^{\text {th }}$ \\
\hline 5 & P5 & 0.004856 & 0.005595 & 0.535334 & $11^{\text {th }}$ \\
\hline 6 & P6 & 0.000464 & 0.010122 & 0.956176 & $2^{\text {nd }}$ \\
\hline 7 & P7 & 0.00647 & 0.004883 & 0.430116 & $13^{\text {th }}$ \\
\hline 8 & P8 & 0.003074 & 0.004011 & 0.566098 & $10^{\text {th }}$ \\
\hline 9 & P9 & 0.003566 & 0.007649 & 0.682048 & $6^{\text {th }}$ \\
\hline 10 & P10 & 0.007926 & 0.00401 & 0.335944 & $15^{\text {th }}$ \\
\hline 11 & P11 & 0.005914 & 0.005383 & 0.476487 & $12^{\text {th }}$ \\
\hline 12 & P12 & 0.00041 & 0.008081 & 0.951754 & $3^{\text {rd }}$ \\
\hline 13 & P13 & 0.001407 & 0.005971 & 0.809354 & $5^{\text {th }}$ \\
\hline 14 & P14 & 0.000226 & 0.009174 & 0.976007 & $1^{\text {st }}$ \\
\hline 15 & P15 & 0.001048 & 0.006981 & 0.869425 & $4^{\text {th }}$ \\
\hline
\end{tabular}

Table 6: Summary of the closeness ratio and ranking

\section{MANAGERIAL IMPLICATIONS}

According to the society of Indian Automobile Industry (SIAM, 2017), the contribution of the Automobile Industries in India to GDP has increased from $2.77 \%$ in 1992-1993 to about $7.1 \%$ now and accounts for about $49 \%$ of manufacturing GDP (2015-2016). The turnover of the automobile industry is approximately US\$ 67 billion (2016-2017). Hence, the Automobile industry in India is one of the pillars of Indian growth history. However, the industry, for the last few years is showing slanginess in sales and growth due to slowdown all over the globe. Recently, numerous studies have carried out to explore and develop performance ethics in the automobile industry for understanding its key aspects of sustainability and growth aspects. As an outcome, researchers and academicians tried hard to achieve better performance variables and ultimately the performance. Therefore, the performance of the automobile industries has been prioritized through the identification of fifteen variables or parameters of this research articles so as to accompany present automobile industry hoping that it increases the performance of the industry so as to have sustainability in the growth and production also the identification of the fifteen variables of GSCM in automobile industries, will, in turn, provide a guidelines for the measurement of the performance to a level par with the standards in not only Indian but global context as well.

Published By:

Blue Eyes Intelligence Engineering \& Sciences Publication (C) Copyright: All rights reserved. 
The findings suggest that "Suppliers' willingness towards GSCM", "Adoption of technology advancements" and "Top Management Commitment" is the most impactful variables that affect the implementation of GSCM in the Indian automobile industry. The supplier's willingness towards GSCM may create a positive implementation environment among the chain partners and ultimately may initiate the process. One of the most important barriers for GSCM is the supplier's reluctance towards GSCM as Indian automobile industries are concerned, hence this variable may prove to be the most important in another way. The adoption of technological advancement also creates a positive impact on the competitive edge of the industry. Top management commitment is one of the key supports for the implementation and performance of the GSCM in Indian automobile industries. Besides these variables all other variables which are identified and ranked in this article are obtained from the rigorous literature review, consultation of the academicians, researchers, and industry people, therefore are the core parameters of the tool for measuring the performance of the GSCM. Determination of variables for effective performance measurement to achieve sustainability in the overall growth of the industry. It will also provide guidelines for other industries as a measuring pathway. Thus, it is clear that a comprehensive performance measurement approach will create growth, sustainability is not only profits but also may prove to be a support for the Indian automobile industries facing challenges using these variables.

\section{CONCLUSION, LIMITATION, AND FUTURE SCOPE OF THIS STUDY}

Green Supply chain management has emerged as an important and vital aspect in today's marketplace and

a very much essential philosophy to the sustainability of the organizations and supply chains. The key performance variables for GSCM are thus, become very necessary ingredients to improve the performance of GSCM in the Automobile industries and their attributes relevant to the system under study. Green Supply Chain Management performance variables may range up to a wide variety but for our study they include. The TOPSIS method is applied to final ranking preference in descending order, thus allowing relative performance to be compared. Based on data analysis, the "Supplier Willingness towards," "Adoption of Technology Advancement," "Top Management Commitment" emerged as the top three best key parameters with the value of 0.97 , 0.9561 , and 0.9517 , respectively which achieved the best relative closeness to the ideal solution. While "Organizational Motivating," "Encouragement of sustainable product," and "Government Support systems" are identified as the bottom three parameters having closeness coefficients are $0.43,0.38$, and 0.33 , respectively.

The objective of this study is to categorize key factors for sustainable development of the automobile industry with special reference of Indian firms. A strong structural relationship between various parameters is evident as the bottom three parameters are significant. Some of the trademarks of the automobile industry are high quality, core competency, the economy of scope, efficiency, and profitability. The industry needs to embrace a new business model that provides a holistic understanding to cover social and economic factors for long term sustainability. The study classifies critical sustainable goal parameters of the Indian automobile industry. However, there are some limitations in terms of small sample size. The thematic data analysis done using TOPSIS shows the impact of sustainability metrics on the industry. Future studies may focus on criteria like vendor selection, customer, distribution in Bayesian belief networks to increase productivity and performance across operations. Moreover, future studies may refer to this model to analyze other industries

\section{REFERENCES:}

1. Abdel-Baset, M., Chang, V., \& Gamal, A. (2019). Evaluation of the green supply chain management practices: A novel neutrosophic approach. Computers in Industry, 108, 210-220.

2. Abdel-Baset, M., Chang, V., Gamal, A., \& Smarandache, F. (2019). An integrated neutrosophic ANP and VIKOR method for achieving sustainable supplier selection: A case study in importing field. Computers in Industry, 106, 94-110.

3. Ahi, P., \& Searcy, C. (2013). A comparative literature analysis of definitions for green and sustainable supply chain management. Journal of cleaner production, 52, 329-341.

4. AlKhidir, T., \& Zailani, S. (2009). Going green in supply chain towards environmental sustainability. Global Journal of Environmental Research, 3(3), 246-251.

5. Bachofner, J.A., Valli, P. V., Kröger, A., Bergamin, I., Künzler, P., Baserga, A., ... \& Semela, D. (2017). Direct antiviral agent treatment of chronic hepatitis $\mathrm{C}$ results in rapid regression of transient elastography and fibrosis markers fibrosis-4 score and aspartate.

6. Balasubramanian, S. (2012). A hierarchiacal framework of barriers to green supply chain management in the construction sector, Journal of Sustainable Development; 5(10), 15-27.

7. Balasubramanian, S., \& Sundarakani, B. (2019). Assessing the green supply chain management for the United Arab Emirates construction industry. In Green Business: Concepts, Methodologies, Tools, and Applications (1306-1327). IGI Global.

8. Belhadi, A., Kamble, S.S., Zkik, K., \& Cherrafi, A. (2019). The integrated effect of big data analytics, lean six sigma, and green manufacturing on the environmental performance of manufacturing companies: The case of North Africa. Journal of Cleaner Production, 252, 1-14.

9. Carter, C.R., \& Liane Easton, P. (2011). Sustainable supply chain management: evolution and future directions. International journal of physical distribution \& logistics management, 41(1), 46-62.

10. Cavusgil, E., Seggie, S.H., \& Talay, M.B. (2007). Dynamic capabilities view: Foundations and research agenda. Journal of marketing theory and practice, 15(2), 159-166

\section{AUTHORS PROFILE}

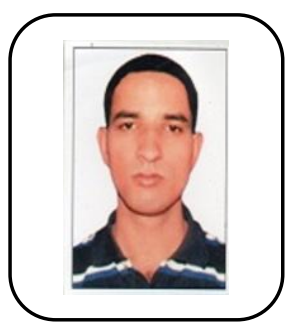

Deepak kumar Pathak, Research scholar, Department of Mechanical Engineering, MANIT Bhopal.

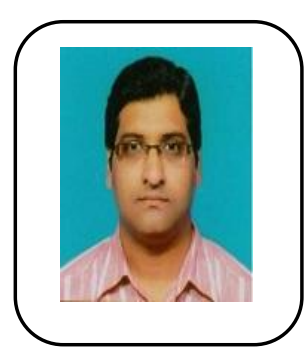

Dr. Ajay Verma, Assistant Professor, Department of Mechanical Engineering, MANIT Bhopal.

Published By:

Blue Eyes Intelligence Engineering 